\title{
A case of polycythaemia vera presenting with intramuscular chest wall haematoma
}

\author{
S. Kheterpal, F. Sayegh and A. Cader \\ The General Hospital, Steelhouse Lane, Birmingham B4 6NH, UK
}

\begin{abstract}
Summary: A 40 year old male, previously well, presented with a posterior chest wall haematoma. Computerized tomography and ultrasound showed this to be intramuscular. Haematological indices were consistent with a diagnosis of polycythaemia vera. The haematoma and indices responded to hydroxyurea and venesection. This rare presentation of polycythaemia vera in a young person is described and the haemorrhagic complications of polycythaemia vera discussed.
\end{abstract}

\section{Introduction}

Intramuscular haemorrhage is common in coagulation factor deficiencies but rare in myeloproliferative disorders and particularly so in young patients. Polycythaemia may present with its major complications of either thrombosis or haemorrhage. ${ }^{1}$ The bleeding usually presents as ecchymosis, gastrointestinal haemorrhage or epistaxis. In a review of the literature only two cases of intramuscular haemorrhage in polycythaemia vera (PV) have been described and these occurred in patients over the age of $80 .^{2-4} \mathrm{We}$ report a 40 year old man with a posterior chest wall intramuscular haematoma as the presenting feature of PV. The haemorrhagic complications of PV are discussed.

\section{Case report}

A 40 year old man was admitted as an emergency in September 1990 having developed a large swelling on the right posterior chest wall overnight. He was previously well and there was no obvious history of trauma. His pulse and blood pressure were normal and there was no other evidence of haemorrhage. There was no clinical cardiac or respiratory abnormality. Abdominal examination revealed mild splenomegaly. There was a $26 \times 22 \times 5 \mathrm{~cm}$ tense fluctuant swelling on the right posterior chest wall. There was good range of movement at the neck and shoulder.

Ultrasound and computed tomographic (CT) scan (Figure 1) confirmed the presence of haematoma in the muscle planes. Admission haemato-

Correspondence: A. Cader, M.R.C.Path., Hospital of St Cross, Barby Road, Rugby, Warks CV22 5PX, UK. Accepted: 18 October 1991 logical indices showed haemoglobin $22 \mathrm{~g} / \mathrm{dl}$, white cell count $14.2 \times 10^{9} / 1$ (neutrophilia), platelets $662 \times 10^{9} / 1$ and haematocrit 0.666 . Prothrombin time, activated partial thromboplastin time, factor VIII, fibrinogen, bleeding time, neutrophil alkaline phosphatase, serum $B_{12}$, platelet aggregation studies and arterial blood gases were normal. Sternal marrow showed an increase in all three cell lines. Red cell mass was $43 \mathrm{ml} / \mathrm{kg}$, plasma volume $42 \mathrm{ml} /$ $\mathrm{kg}$ and serum urate $640 \mu \mathrm{mol} / \mathrm{l}$.

Within 24 hours the haematoma had increased in size and the haemoglobin transiently fell to $14.6 \mathrm{~g} /$ $\mathrm{dl}$, white cell count $6.4 \times 10^{9} / 1$ and platelets $769 \times 10^{9} / 1$ due to 'auto-venesection'. The haematoma resolved spontaneously over the next few days with a mild associated rise in serum bilirubin. The patient was treated with hydroxyurea and allopurinol with intermittent venesection. He remained well throughout and 6 months later indices showed haemoglobin $15.2 \mathrm{~g} / \mathrm{dl}$, white cell count $7.2 \times 10^{9} / 1$ and platelets $334 \times 10^{9} / 1$.

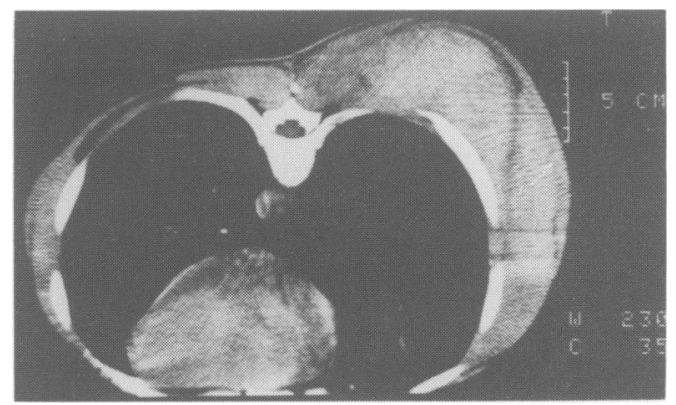

Figure 1 CT scan of transverse section of thorax showing intramuscular haematoma. 


\section{Discussion}

It is reported that less than $5 \%$ of cases of PV occur under the age of $\mathbf{4 0}$ and that the complication of haemorrhage as the presenting feature occurs in only $1.7 \%$ of such young patients. ${ }^{5,6}$ The bleeding is usually mucocutaneous and intramuscular haemorrhage in this age group has not been previously reported as a feature.

The cause of the haemorrhagic tendency in PV is not clear. Patients with myeloproliferative disorders can have normal coagulation but those with thrombocythaemia may have an increased bleeding tendency. ${ }^{7}$ Various platelet abnormalities including decreased adhesiveness, defective aggregation and reduced serotonin uptake have been described in association with thrombocythaemia. ${ }^{8,9}$

\section{References}

1. Berlin, N.I. Diagnosis and classification of polycythaemias. Semin Haematol 1975, 12: 339-351.

2. Shita, A. \& Gossuin, A. Haematoma of the rectus sheath complicated by an acute abdomen in a patient with polycythaemia vera. Clin Belg 1981, 80: 158-159.

3. Mittal, R.R. \& Meisler, A.I. Spontaneous massive abdominal wall haematoma in polycythaemia vera. Acta Haematol 1984, 72: $128-130$.

4. Isles, C. \& Strachen, R.W. Polycythaemia vera presenting as an acute abdomen. Postgrad Med J 1981, 57: 314-316.

5. Najean, Y., Mugnier, P., Dresch, C. \& Rain, J.-D. Polycythaemia in young people: an analysis of 58 cases diagnosed before 40 years. $\mathrm{Br} J$ Haematol 1987, 67: 285-291.

6. Prochazka, A.V. \& Markoute, H.L.J. The epidemiology of polycythaemia vera in England and Wales 1968-1982. Br J Cancer 1986, 53: 59-64.
It has been found that platelet function is improved when the count is reduced suggesting ${ }_{3}$ that impaired function occurs as a result of the high count rather than dyspoesis. Another hypothesis is ${ }_{\llcorner}$ that there is a state of chronic disseminated intravascular coagulation with excess production of platelets which are themselves hyperaggregable.o This can be thought to explain the thrombotic음 tendency and disaggregation with subsequent $\overline{\bar{c}}$ release of ineffective platelets resulting in haemor- $\mathbb{D}$ rhagic complications. However, bleeding may occur in cases where platelet count, bleeding time, platelet adhesiveness and aggregation may be nor- $-\circ$ mal. Acquired Von Willebrand's disease has also $\overrightarrow{-}$ been implicated as causing bleeding in this clinical setting. ${ }^{10}$

7. Stathakis, N.E., Papayannis, A.G., Arapakis, G. \& Gardinas, $\rightarrow$ C. Haemostatic defects in polycythaemia vera. Blut 1974, 29:음 $77-85$.

8. Schafer, A.I. Bleeding and thrombosis in the myelopro- liferative disorders. Blood 1984, 64: 1-12.

9. Berger, S., Aledort, L.M., Gilbert, H.S., Hanson, J.P. $\&$ Wasserman, L.R. Abnormalities of platelet function in patients with polycythaemia vera. Cancer Res 1973, శુ:లి 2683-2686.

10. Fey, M.F. Spontaneous massive abdominal wall haematoma in polycythaemia vera. Acta Haematol 1985, 73: 122-128. 